\title{
Evaluation of Nanoemulsion Concentrate Botanical Fungicide from Neem, Citronella and Eugenol Oil Using Palm Oil Based Surfactant
}

\author{
Melati Septiyanti ${ }^{1,}$,, Muhammad Rizky Mulyana ${ }^{2}$, Rahmawati Putri ${ }^{1}$, Yenny Meliana ${ }^{1}$ \\ ${ }^{1}$ Research Centre for Chemistry, Indonesian Institute of Sciences, South Tangerang, Indonesia \\ ${ }^{2}$ Directorate of National Standard for Measurement Unit of Thermoelectric and Chemistry, National Standardization Agency of Indonesia, \\ South Tangerang, Indonesia
}

Email address:

mela003@lipi.go.id (M. Septiyanti),mulyanarizky3003@gmail.com (M. R. Mulyana), rahmawepe2@gmail.com (R. Putri), yenn001@lipi.go.id (Y. Meliana)

${ }^{*}$ Corresponding author

\section{To cite this article:}

Melati Septiyanti, Muhammad Rizky Mulyana, Rahmawati Putri, Yenny Meliana. Evaluation of Nanoemulsion Concentrate Botanical Fungicide from Neem, Citronella and Eugenol Oil Using Palm Oil Based Surfactant. American Journal of Physics and Applications. Vol. 7, No. 1, 2019, pp. 14-20. doi: 10.11648/j.ajpa.20190701.13

Received: December 14, 2018; Accepted: January 23, 2019; Published: February 22, 2019

\begin{abstract}
Pathogenic fungi has became a problem and caused crop failure. Synthetic fungicide was commonly used to control the growth of the fungi, however it has an adverse effect which can pollute the environment. As an alternative, botanical fungicide can be used as antifungal agent which is safer for environment. Neem oil has been reported as inhibitor for pathogen fungi, while eugenol and citronella oil have been proved to have antifungal effect against Aspergillus Niger. The essential oil does not dissolved naturally in water, therefore it is important to formulate this oil using palm oil based surfactant in order to form water dispersed formulation which might enhance the effectiveness of the formulation. This study investigate the best emulsifiable concentrate (EC) formulation using palm oil based surfactant and also the residue in water and soil in order to ensure that the formulation is safe for environment. Nanoemulsion was prepared by mixing essential oil and surfactant with ratio of $60: 40,70: 30,80: 20,90: 10$ each. The stability was investigated by observing creaming height and particle size overtime. The residue evaluation was done by analyzing TSS, TDS, COD value for water residue and GCMS analysis for soil residue. The best formulation was achieved with composition of neem, eugenol and citronella by $33 \%$ each, surfactant MES 20\%, PDO 10\% and PMO 70\% with oil/surfactant ratio 60/40 and solvent ethanol ratio 1:2. The droplet size ranged between $350-480 \mathrm{~nm}$ and polydispersity index $0.3-0.5$. This fungicide formulation also considered allowable by regulatory standard where the value of TDS was in range 1-100 mg/l, TSS 0-04 mg/l, COD 30-1270 mg/l and pH was in range 5-5.7. The result of Soil residue analysis shows that the essential oil derivatives still remain in soil for five days. It is expected that this result can become reference for fungicide companies and other related stakeholder to formulate stable botanical fungicide.
\end{abstract}

Keywords: Emulsion Stability, Fungicide, Residue, Emulsified Concentrate, Essential Oil

\section{Introduction}

Pathogenic fungi can infect the plant and caused crop failure. In order to overcome this problem, farmers commonly use fungicide to prevent the growth of fungi. The use of chemical fungicide is a common way to control plant disease, but it can cause harmful impacts for human health and environment [1]. Natural substances can substitute synthetic fungicide for safer and environmental friendly product. Neem with active agent azadirachtin has been reported can inhibit the growth of pathogen fungi, insects, mites, nematodes and also snail and has been considered harmless for human [2]. Citronella oil has antifungal effect against Aspergillus Flavus on rubberwood plant (Hevea Brasiliensis) [3] and the nanoemulsions formulation combination of neem and citronella oils can control phytopathogenic fungi, Rhizoctonia solani and Sclerotium rolfsii in tuber plants [4]. Other than neem and citronella, 
eugenol oil nanoemulsion can also be used as natural fungicide for pathogen fungi Fusarium oxysporum f.sp vasinfectum in cottonseeds plants by passing through the cell wall and cytoplasmic membrane, inactivate the essential enzyme and disturb genetic functionality [5]. A study by Aulifa et al also proved that eugenol has antifungal effect against phytophthora palmivora in cocoa plants [6].

Naturally these essential oils have antifungal activity yet these substances can't dissolve in water. It is very important to formulate insoluble active agent to become stable fungicide for effective antimicrobial activity [7]. One of the formulation type of fungicide is Emulsifiable concentrate (EC). This formulation can be formulated by dissolving the active agent with surfactant and solvent. EC formulation commonly applied by diluting it in water to produce milky emulsion with little creaming and no oil separation. However, emulsion stability may become a problem in this formulation after dilution [8].

Surfactant is one the key factor to form stable emulsion from EC formulation. Surfactant is a molecule which contains both hydrophilic and hydrophobic groups which reduces interfacial tension between fluid and fluid system. Commonly, surfactant is a derivation of petroleum, but recent study reported that surfactant can be developed from oil palm derivatives which is more environmental friendly [9]. The emulsion from EC formulation can be prepared by spontaneous emulsification. Common issue of the emulsion is destabilization because of flocculation, coalescene and creaming, breaking and ostwald ripening. The stability can be maintained by controlling their composition and microstructure by adding the right amount of surfactant [10].

Thus, this study investigated the optimum fungicide EC formulation to produce stable nanoemulsion to enhance the emulsion stability from neem, citronella and eugenol oil combination with palm oil based surfactant which is safer for environment and all ingredients is derived from natural substances. The stability test was done for six hours and the most stable formulation was analyzed using particle size analyzer to observe the droplet size. The residue in water and soil was analyzed to evaluate the effect of the fungicide formulation to environment.

\section{Materials and Method}

\subsection{Material}

Material used in this study were pure neem oil from Indoneem, eugenol and citronella oil usp, Indonesia, anionic surfactant methyl ester sulfonate (MES) HLB 0.5, nonionic surfactant polyethylene glycol dioleate (PDO) HLB 8, polyethylene glycol monooleate (PMO) HLB 13 from Sigma Aldrich, United States and ethanol for analysis from Merck, Germany.

\subsection{Nanoemulsion Preparation}

Oil phase was made by mixing neem, eugenol and citronella oil and surfactant methyl ester sulfonate (MES), nonionic surfactant polyethylene glycol dioleate (PDO), polyethylene glycol monooleate (PMO) separately with composition as shown in table 1 with variation oil/surfactant ratio as shown in Table 2 at $1000 \mathrm{rpm}$ for two hours at room temperature. Oil and surfactant mixture was mixed for two hours at $1000 \mathrm{rpm}$ at room temperature. Ethanol was added into oil and surfactant mixture with ratio $1: 2 \mathrm{v} / \mathrm{v}$. Nanoemulsion was spontaneously formed by adding water into oil phase with ratio $1: 10$.

\subsection{Nanoemulsion Stability Evaluation}

Preliminary nanoemulsion stability was observed for six hours then the creaming and separation height was recorded every ten minutes. The most stable formulation with no creaming and separation was measured its particle size using Horiba Nano partica SZ-100 for six hours and recorded every ten minutes.

Table 1. Fungicide Formulation.

\begin{tabular}{lll}
\hline Component & & Composition (w/w) \\
\hline \multirow{3}{*}{ Oil } & Neem & $33 \%$ \\
& Eugenol & $33 \%$ \\
& Citronella & $33 \%$ \\
\multirow{3}{*}{ Surfactant } & MES & $20 \%$ \\
& PDO & $10 \%$ \\
& PMO & $70 \%$ \\
\hline
\end{tabular}

Table 2. Fungicide Formulation Oil/Surfactant Ratio.

\begin{tabular}{lll}
\hline Formula & Oil Fraction & Surfactant Fraction \\
\hline F1 & 60 & 40 \\
F2 & 70 & 30 \\
F3 & 80 & 20 \\
F4 & 90 & 10 \\
\hline
\end{tabular}

\subsection{Fungicide Residue Evaluation}

The residue of fungicide in water was done by adding fungicide into surface water then observed for five days with parameter Total dissolve solid (TDS) and $\mathrm{pH}$ using $\mathrm{pH}$ meter Consort C3020, Total suspended solid (TSS) by gravimetry method and Chemical oxygen demand (COD) using spectrophotometry method. The residue of fungicide in soil was done for five days. The fungicide was sprayed to soil and the soil sample was extracted using methanol then analyzed using GC-MS Agilent.

\section{Result and Discussion}

\subsection{Oil/Surfactant Ratio Effect on Nanoemulsion Kinetic Stability}

Emulsions are dispersions of two or more immiscible phase using surfactant [11]. Surfactant with HLB range 2-6 stabilizes water in oil emulsions while surfactant with HLB range 8-18 stabilizes oil in water emulsions. With mixed surfactant, the desired HLB can be calculated based on concentration and individual HLB number on each surfactant [12]. In this study, the HLB of neem oil is 9, eugenol oil is 6 , citronella oil 12 so the HLB mixture is 9. The emulsion was 
stable in surfactant mixture with HLB 10 [13]. Polyethylene monooleate (PMO) and polyethylene dioleate (PDO) as main composition of surfactant mixture is a non-ionic surfactant maintained the emulsion stability by providing ionic strength and improve dissolution of essential oil [14]. Methyl ester sulfonate (MES) as anionic surfactant has negative charged particle and stabilize the emulsion through hydrophobic binding of the surfactant tails to carbon chain [15]. The combination of PMO and PDO as non-ionic surfactant manage the crystallization and MES as anionic surfactant provide force to maintain particle stabilization and crystallization balance [16]. Surfactants with HLB value higher than 10 are known to be hydrophilic, while surfactant with HLB value lower than 10 are lipophilic [17]. MES and PDO tend to oil soluble while PMO tend to water soluble. The composition of surfactant $70 \%$ consist of PMO indicate a dominant hydrophilic affinity which interact with particle surface in water through hydrogen bonding to form oil in water nanoemulsion [18].

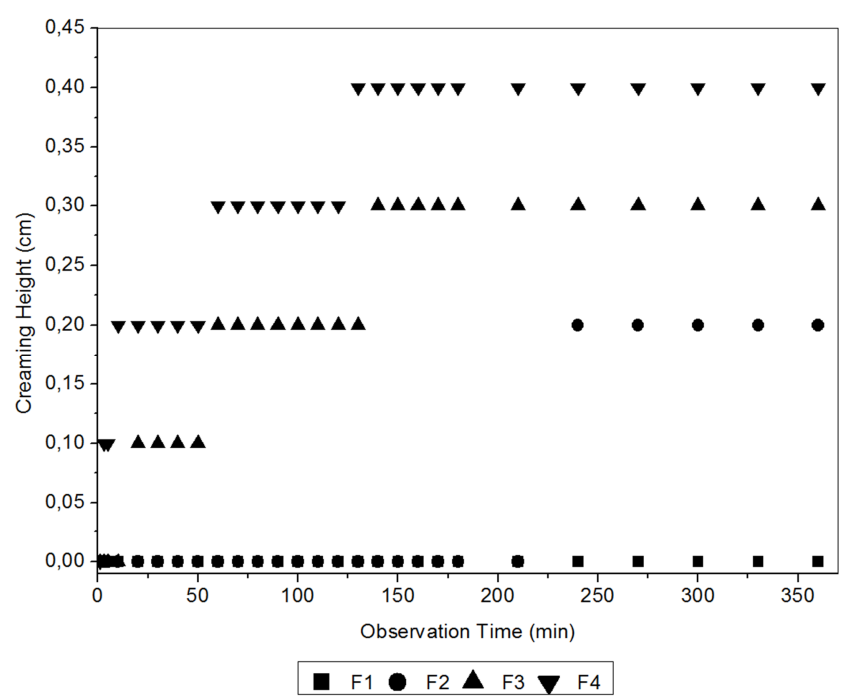

Figure 1. Nanoemulsion Stability in 6 Hours Observation.

The emulsion stability was observed manually for six hours and the destabilization phenomenon was recorded every ten minutes. The result of the stability test is shown in Figure 1. Formula F3 and F4 show destabilization at minutes20 with creaming height $0.3 \mathrm{~cm}$ and minutes- 3 with creaming height $0.4 \mathrm{~cm}$. Formula F2 shows creaming formation at minutes-240 with creaming height $0.2 \mathrm{~cm}$, while formula $\mathrm{F} 1$ remain stable for 6 hours. Formula F3 consists of $80 \%$ oil and $20 \%$ surfactant and formula F4 is $90 \%$ oil and $10 \%$ surfactant. It is seen that creaming form in high oil/surfactant ratio because inadequate amount of surfactant and cosurfactant in lowering the interfacial tension [19]. Formula 1 and 2 have lower oil fraction, $60 \%$ and $70 \%$ respectively and shows better stability. This corresponds to a study by Matsaridou where the range of oil/surfactant between $6: 4$ and $7: 3$ covered the region of emulsification process [14]. Yet, as seen in Figure 1, in formula F2 creaming was still occurred if it's compared with formula F1 which remain stable for 6 hours. It can be concluded that lower oil fraction produce more stable oil in water emulsion system. Low oil/surfactant ratio perform phase inversion composition emulsification by breaking an intermediate structure with superior water content forming nanoemulsion droplets which is kinetically stable [20].

\subsection{Oil/Surfactant Ratio Effect on Nanoemulsion Particle Size Stability}

Formula F1 and F2 were considered the most stable formulation and the analysis continues to particle size analysis to know the droplet size stability as seen in Figure 2 and Figure 3.

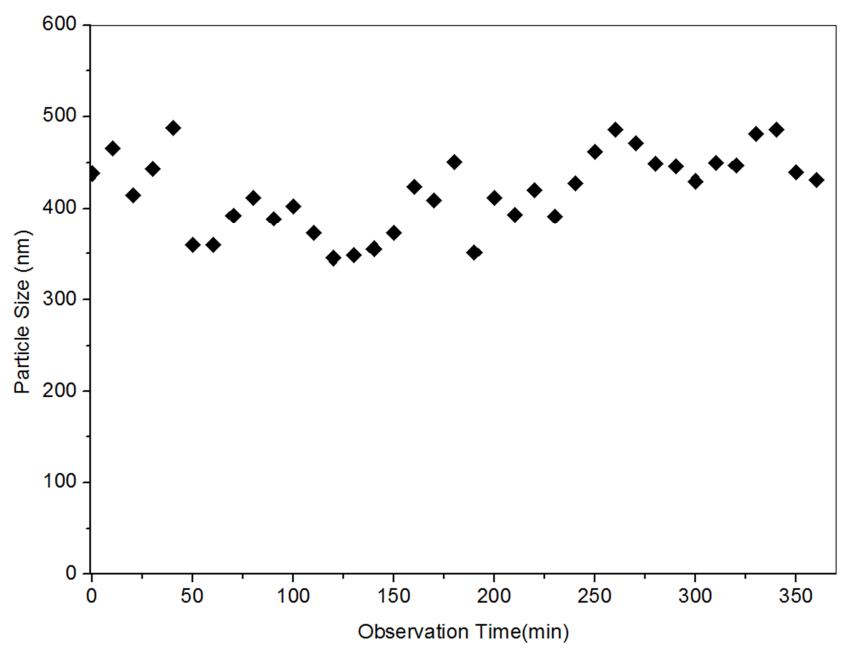

Figure 2. Formulation F1 Particle Size Analysis in 6 Hours Observation.

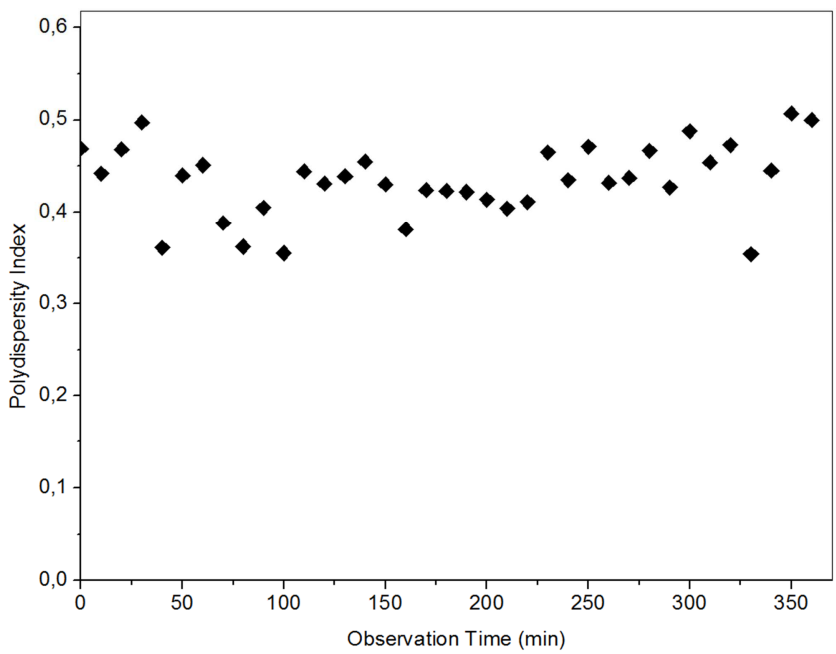

Figure 3. Formulation F1 Polydispersity Index in 6 Hours Observation.

Figure 2 shows particle size analysis of formula F1. The particle size was ranged between 350-480 nm which categorize as nanoemulsion [21], polydispersity index was ranged between 0.3-0.5 and there was no significant change in six hours observation. The polydispersity index represent information about the homogeneity of the particle size while the value below 0.3 shows narrow size distribution which means the particles are monodisperse [22]. Formula F1 showed narrow to moderate homogeneity during observation 
for 6 hours. Nanoparticles tend to aggregate due to van der waal forces and may induce the increase of polydispersity index value [23]. The main constituent of neem, eugenol and citronella oil is oleic acid where the surfactant also contained the same fatty acid composition. The same structure causes good interaction between oil and surfactant so the surfactant can fully cover the surface of oil droplets, resulting excellent physical stability [24]. The use of PMO and PDO as nonionic surfactant associate with amphiphilic polymers which can form viscoelastic interfacial film at oil/water interface to prevent Ostwald ripening destabilization phenomenon [25]. The high surfactant concentration also increased the interfacial area between water phase and oil phase which yielded smaller droplet [26].

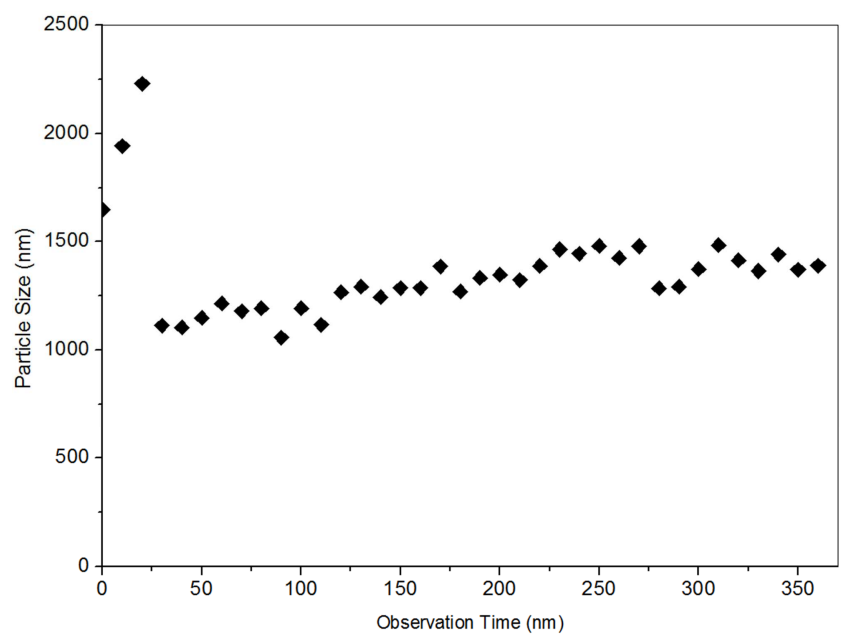

Figure 4. Formulation F2 Particle Size Analysis in 6 Hours Observation.

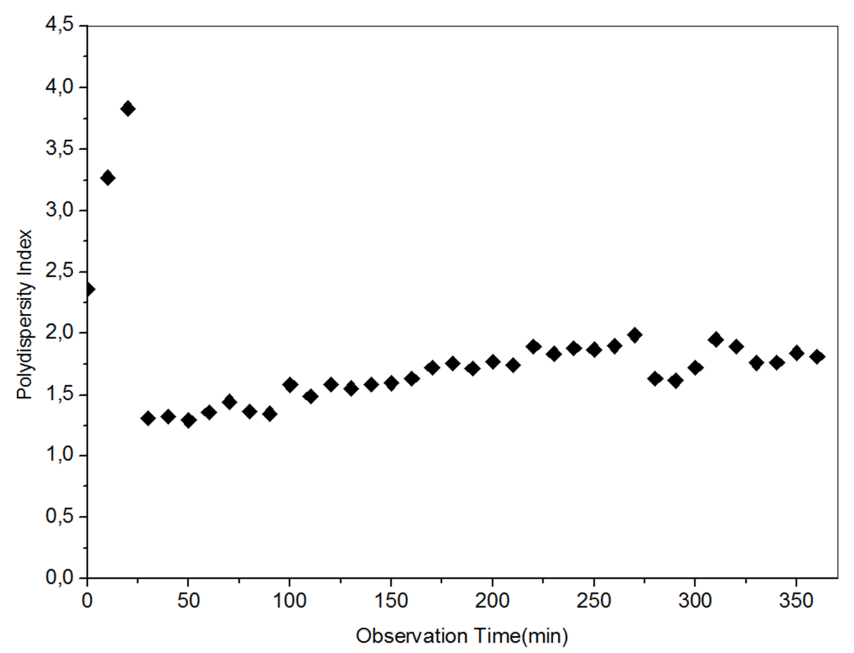

Figure 5. Formulation F2 Polydispersity Index in 6 Hours Observation.

The Formula F2 shows different particle size profile where the size was ranged between 1000-2300 nm and polydispersity index 1-3 as shown in Figure 4 and Figure 5. Polydispersity index larger than 0.7 indicate that the sample has wide range particle size [27]. The emulsion droplet size was unstable and had bigger particle size at the first 20 minutes, this instability and high polydispersity might be caused by the excess oil phase in emulsion system [28]. At lower surfactant concentration the oil-water interfacial layer is not enough to fully cover the surface droplet thus the coalescence and flocculation occurred. The droplets which have no surfactant layer will merge together and form bigger droplet with wide range particle size. This phenomenon occurs when the droplet collide velocity higher than surfactant absorption rate in interfacial layer [29]. It can be concluded oil and surfactant in ratio 70/30 doesn't sufficient to form stable emulsion with uniform particle size while in ratio $60 / 40$ can stabilize the emulsion system and form nanoscale particle size.

\subsection{Fungicide Water and Soil Residue Evaluation}

To make sure that the fungicide is safe for environment, residue evaluation was done in water and soil for five days. The fungicide was doused to water and then analyzed with parameter TDS, TSS, $\mathrm{pH}$ and COD. The analysis result is shown in Table 3.

Table 3. Water Residue Evaluation.

\begin{tabular}{lllll}
\hline Day & TDS (mg/l) & TSS (mg/l) & COD (mg/l) & pH \\
\hline 1 & 1.36 & 0.3819 & 28.2 & 5.06 \\
3 & 101.6 & 0.0032 & 767 & 5.74 \\
5 & 76.3 & 0.0157 & 1270 & 5.54 \\
\hline
\end{tabular}

Table 3 shows the value of TDS was in range 1-100 mg/l, TSS 0-04 mh/1, COD 30-1270 mg/l and $\mathrm{pH}$ was in range 55.7. Based on The Environment Regulation No 01, 2010 about Procedures of Water Pollution Control in Indonesia, TDS and TSS below 250 and $100 \mathrm{mg} / \mathrm{l}$ is categorized low concentration domestic waste water while COD below 250 $\mathrm{mg} / \mathrm{l}$ is categorized low and below 1000 was categorized high concentration domestic water [30]. Based on the analysis result, waste water from this fungicide was found to have relatively low TSS and TDS. The composition TSS may contain sand, silt, mineral precipitates and biological mater while TDS may contain salts, metalloids and dissolved organic matter [31]. Low TSS value was caused by the formulation of fungicide in stable emulsion form which was not contained suspended matter. TDS value was affected by organic constituents from fungicide active agent and surfactant.

COD value was relatively high yet still in regulatory standard. COD is the quantity of oxidant that reacts with the sample under certain condition [32]. High COD value was caused by the presence of oxidizable chemicals compound from essential oil and surfactant derivatives in fungicide formulation, such as fatty acids, esters and its derivatives. The chemical constituents were shown in GCMS figures below and specified in Table 4. 
Table 4. Soil Sample Extract Compound from GCMS Analysis.

\begin{tabular}{llll}
\hline Day & Retention Time & Area\% & Compound \\
\hline 1 & 4.865 & 85.47 & Bis(trimethylsilyl)trifluoroacetamide \\
& 11.767 & 6.66 & 2-Propenoic acid, 2-methyl-,1,2-ethanediyl ester \\
3 & 20.047 & 7.87 & Palmitic Acid \\
& 11.767 & 17.71 & 2-Propenoic acid, 2-methyl-, 1,2-ethanediyl ester \\
& 20.680 & 52.34 & Ethyl Vanilin \\
& 21.736 & 15.19 & 1,3a-Ethano(1H)inden-4-ol, octahydro-2,2,4,7a-tetramethyl- \\
5 & 23.133 & 14.76 & Hexanedioic acid, bis(2-ethylhexyl) ester \\
& 11.766 & 4.79 & 2-Propenoic acid, 2-methyl-,1,2-ethanediyl ester \\
\hline
\end{tabular}

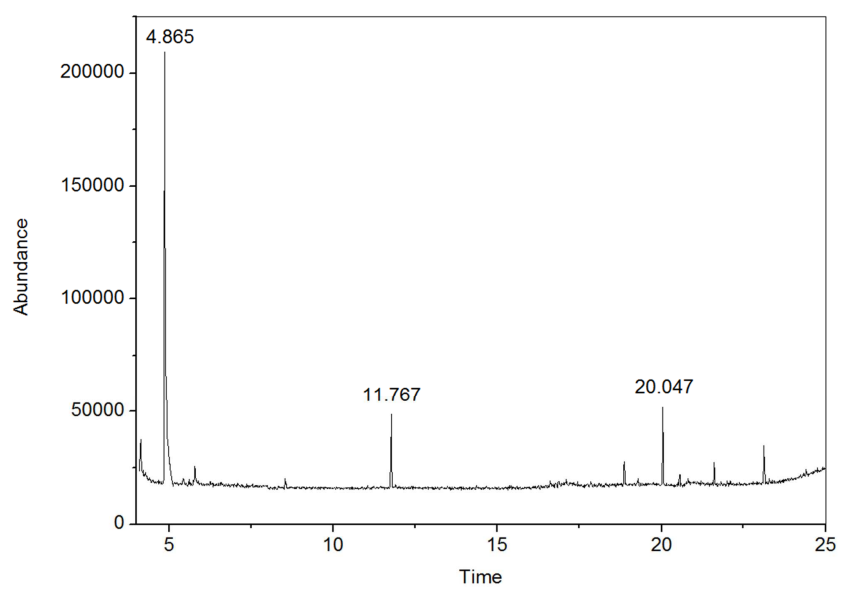

Figure 6. GCMS Peak of Soil Sample Extract for Day 1.

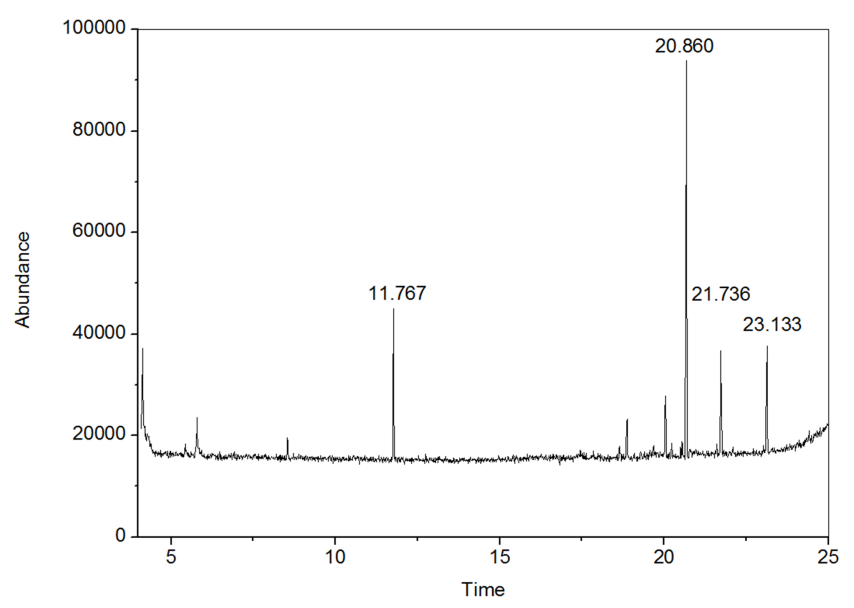

Figure 7. GCMS Peak of Soil Sample Extract for Day 3.

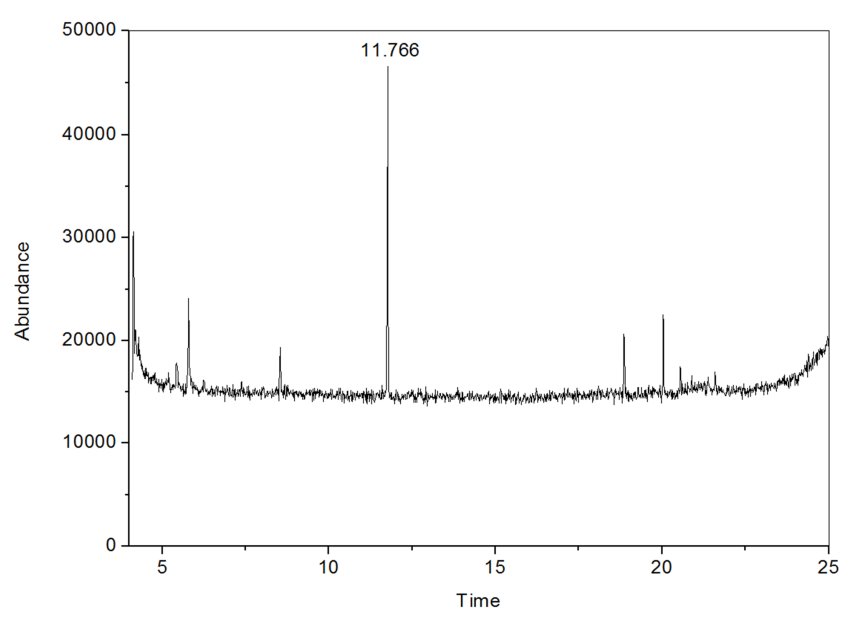

Figure 8. GCMS Peak of Soil Sample Extract for Day 5.
The analysis of residue in soil can be seen in Table 4. It is shown the derivatives of neem, citronella and clove oil. For five days observation, still remained ester compound and derivatives compound from eugenol, ethyl vanillin and Hexanedioic acid [33, 34] and 2-Propenoic acid, 2-methyl,1,2-ethanediyl ester from citronella oil derivatives [35]. Palmitic acid constituent was from palm oil based surfactant. MES, PMO and PDO is derived from crude palm oil or palm kernel oil which has C16-C18 fatty acids composition [3638]. Based on five days observation, the chemical constituent still remained in soil. The presence of fungicide chemical constituents might be caused by soil-fungicide interaction trough hydrogen bonding (H-bonding). Esters constituents, non-ionic polar and anionic fungicide may interact with soil by H-bonding [39]. Yet, essential oils and extract as fungicide active agent are biodegradable and have less environmental risk compare with synthetic fungicide [1]. Degradation of fungicides in soil may happen by leaching, drainage, dilution and runoff. The presence of surfactant and solvent can affect fungicide degradation process but the nanotecnology in fungicide formulation can provide controlled or slow release of active ingredients to prevent rapid degradation to water bodies [40].

\section{Conclusion}

The best formulation of fungicide formulation from neem, eugenol and citronella oil is formula F1 with composition neem, eugenol and citronella is $33 \%$ each, surfactant MES $20 \%$, PDO $10 \%$ and PMO $70 \%$ with oil/surfactant ratio $60 / 40$ and solvent ethanol ratio 1:2. This formulation remained stable in six hours storage with droplet size ranged between $350-480 \mathrm{~nm}$ and polydispersity index $0.3-0.5$. This fungicide formulation also considered safe for environtment where the value of TDS was in range 1-100 mg/l, TSS 0-04 $\mathrm{mh} / \mathrm{l}$, COD $30-1270 \mathrm{mg} / \mathrm{l}$ and $\mathrm{pH}$ was in range 5-5.7. Soil residue analysis shows that the essential oil derivatives still remain in soil for five days. Based on this result, this fungicide formulation has been proven to be stable and it is expected that fungicide companies and other related stakeholder can use this formulation as reference.

\section{Acknowledgements}

The author would like to thank Prioritas Nasional (PN 2018) Project, Research Centre for Metrology, Indonesian Institute of Sciences (LIPI) and Insentif Riset Sistem Inovasi 
Nasional (Insinas 2018) Project, The Ministries of Research and Higher Education (Kemenristekdikti) for funding this research and Research Centre for Chemistry, Indonesian Institute of Sciences (LIPI) for supporting the laboratory, testing and analysis.

\section{References}

[1] M. Zaker, "Natural Plant Products as Eco-friendly Fungicides for Plant Diseases Control- A Review," Agric., vol. 14, no. 1, pp. 134-141, 2016.

[2] W. Sujarwo, A. P. Keim, G. Caneva, C. Toniolo, and M. Nicoletti, "Ethnobotanical uses of neem (Azadirachta indica A Juss.; Meliaceae) leaves in Bali (Indonesia) and the Indian subcontinent in relation with historical background and phytochemical properties," J. Ethnopharmacol., vol. 189, pp. 186-193, 2016.

[3] S. Jantamas, N. Matan, N. Matan, and T. Aewsiri, "Improvement Of Antifungal Activity Of Citronella Oil Against Aspergillus Flavus On Rubberwood (Hevea Brasiliensis) Using Heat Curing," J. Trop. For. Sci., vol. 28, no. 1, pp. 39-47, 2016.

[4] E. Osman, M. Ali, N. A. Shakil, V. S. Rana, D. J. Sarkar, S. Majumder, P. Kaushik, B. B. Singh, and J. Kumar, "Antifungal activity of nano emulsions of neem and citronella oils against phytopathogenic fungi, Rhizoctonia solani and Sclerotium rolfsii," Ind. Crop. Prod., vol. 108, no. June, pp. 379-387, 2017.

[5] K. A. Abd-Elsalam and A. R. Khokhlov, "Eugenol oil nanoemulsion: antifungal activity against Fusarium oxysporum f. sp. vasinfectum and phytotoxicity on cottonseeds," Appl. Nanosci., vol. 5, pp. 255-265, 2015.

[6] D. L. Aulifa, I. N. P. Aryantha, and S. Sukrasno, "Antifungal Phytophthora Palmivora From Clove Buds (Syzygium Aromaticum L.)," Int. J. Pharm. Pharm. Sci., vol. 7, no. 7, pp. 325-328, 2015.

[7] Y. Meliana, S. Savitri, M. Septiyanti, F. Amriani, S. Aiman, and V. Luvita, "Emulsion Stability of Fungicide From Eugenol and Citronella," in The 15th International Conference on Quality in Research, 2016, pp. 800-807.

[8] D. K. Hazra, R. Karmakar, R. Poi, S. Bhattacharya, and S. Mondal, "Recent advances in pesticide formulations for eco friendly and sustainable vegetable pest management: A review," Arch. Agric. Environ. Sci., vol. 2, no. 3, pp. 232-237, 2017.

[9] P. Permadi, R. Fitria, and Hambali, "Palm oil based surfactant products for petroleum industry," in IOP Conf. Series : Earth and Environmental Science, 2017, pp. 1-6.

[10] S. N. Kale and S. L. Deore, "Emulsion Micro Emulsion and Nano Emulsion: A Review," Syst. Rev. Pharm., vol. 8, no. 1, pp. 39-47, 2017.

[11] T. Tadros, P. Izquierdo, J. Esquena, and C. Solans, "Formation and stability of nano-emulsions," Adv. Colloid Interface Sci., vol. 109, pp. 303-318, 2004.

[12] D. Myers, Surfactant Science And Technology, Third. Hoboken, New Jersey: John Wiley \& Sons, Inc., 2006.
[13] M. Septiyanti, Y. Meliana, S. Aiman, M. Ghozali, and E. Triwulandari, "Formulation of Palm Oil Based Surfactant for Fungicide Emulsifiable Concentrate," in 5th International Symposium on Innovative Bio-Production Indonesia, 2018, pp. 100-106.

[14] I. Matsaridou, P. Barmpalexis, A. Salis, and I. Nikolakakis, "The Influence of Surfactant HLB and Oil / Surfactant Ratio on the Formation and Properties of Self-emulsifying Pellets and Microemulsion Reconstitution," AAPS Pharm. Sci. Technol., vol. 13, no. 4, pp. 1319-1330, 2012.

[15] H. Katepalli, "Formation and Stability of Emulsions: Effect of Surfactant-Particle Interactions and Particle Shape," University of Rhode Island, 2014.

[16] M. B. Zirak and A. Pezeshki, "Effect of Surfactant Concentration on the Particle Size, Stability and Potential Zeta of Beta carotene Nano Lipid Carrier," Int. J. Curr. Microbiol. Appl. Sci., vol. 4, no. 9, pp. 924-932, 2015.

[17] A. I. A. Mohamed, A. S. Sultan, I. A. Hussein, and G. A. Al-muntasheri, "Influence of Surfactant Structure on the Stability of Water-in-Oil Emulsions under HighTemperature High-Salinity Conditions," J. Chem., vol. 2017, pp. 1-11, 2017.

[18] H. Katepalli, A. Bose, T. A. Hatton, and D. Blankschtein, "Destabilization of Oil-in-Water Emulsions Stabilized by Non-ionic Surfactants: Effect of Particle Hydrophilicity," Langmuir, vol. 32, no. 41, pp. 10694-10698, 2016.

[19] M. A. A. Sisak, R. Daik, and S. Ramli, "Study on The Effect of Oil Phase and Co-Surfactant on Microemulsion System," Malaysian J. Anal. Sci., vol. 21, no. 6, pp. 14091416, 2017.

[20] A. Perazzo and V. Preziosi, "Catastrophic Phase Inversion Techniques for Nanoemulsification," in Nanoemulsions: Formulation, Applications, and Characterization, 1st ed., S. M. Jafari and D. J. McClements, Eds. London, United Kingdom: Elsevier Academic Press, 2018, p. 61.

[21] A. Gupta, H. B. Eral, T. A. Hatton, and P. S. Doyle, "Nanoemulsions: formation, properties and applications," Soft Matter, vol. 12, pp. 2826-2841, 2016.

[22] V. Kunasekaran and K. Krishnamoorthy, "Experimental Design for the Optimization of Nanoscale Solid Lipid Particles Containing Rasagiline Mesylate," J. Young Pharm., vol. 7, no. 4, pp. 285-295, 2015.

[23] L. Q. Thang, N. D. Hanh, and D. Q. Duong, "Study On Cause - Effect Relations And Optimization Of Exemestane-Loaded Nanostructured Lipid Carriers," Int. J. Pharm. Pharm. Sci., vol. 9, no. 5, pp. 1-7, 2017.

[24] S. Pengon, N. Chinatangkul, and C. Limmatvapirat, "The effect of surfactant on the physical properties of coconut oil nanoemulsions is," Asian J. Pharm. Sci., vol. 13, no. 5, pp. 409-414, 2018.

[25] M. Maruno, "Characterization and Stability Studies on Vegetable Nanoemulsions Obtained by Low Energy Process," J. Nanomed. Nanotechnol., vol. S8, no. 003, pp. 1-8, 2017.

[26] P. Kundu, A. Agrawal, H. Mateen, and I. M. Mishra, "Stability of oil-in-water macro-emulsion with anionic surfactant: Effect of electrolytes and temperature," Chem. Eng. Sci., vol. 102, pp. 176-185, 2013. 
[27] M. Septiyanti, S. Fahmiati, and Y. Meliana, "Pengaruh Konsentrasi Sampel Terhadap Akurasi Pengukuran Diameter Partikel Nanoemulsi," 11th Annu. Meet. Test. Qual. 2016, pp. 121-127, 2016

[28] P. Izquierdo, J. Feng, J. Esquena, T. F. Tadros, and J. C. Dederen, "The influence of surfactant mixing ratio on nanoemulsion formation by the pit method," J. Colloid Interface Sci., vol. 285, pp. 388-394, 2005.

[29] F. Hasani, A. Pezeshki, and H. Hamishehkar, "Effect of Surfactant and Oil Type on Size Droplets of BetacaroteneBearing Nanoemulsions," Int. J. Curr. Microbiol. Appl. Sci., vol. 4, no. 9, pp. 146-155, 2015.

[30] G. M. Hatta, Peraturan Menteri Negara Lingkungan Hidup Nomor 01 Tahun 2010 Tentang Tata Laksana Pengendalian Pencemaran Air. Indonesia, 2010, p. 9.

[31] B. A. Butler and R. G. Ford, "Evaluating Relationships Between Total Dissolved Solids (TDS) and Total Suspended Solids (TSS) in a Mining-Influenced Watershed," Mine Water Environ., vol. 37, no. 1, pp. 18-30, 2017.

[32] S. A. Hussain, T. Mahmood, and A. Ahsan, "Reduction of Chemical and Biochemical Oxygen Demand After Treatment ofPharmaceutical Effluents," Pakistan J. Pharm., vol. 25, no. 1, pp. 9-13, 2012.

[33] R. Kumar, P. K. Sharma, and P. S. Mishra, "A Review on the Vanillin derivatives showing various Biological activities," Int. J. PharmTech Res., vol. 4, no. 1, pp. 266-279, 2012.

[34] R. Hemalatha, P. Nivetha, C. Mohanapriya, G. Sharmila, C. Muthukumaran, and M. Gopinath, "Phytochemical composition, GC-MS analysis, in vitro antioxidant and antibacterial potential of clove flower bud (Eugenia caryophyllus) methanolic extract," J. Food Sci. Technol., vol. 53, no. 2, pp. 1189-1198, 2016.

[35] L. S. Wei and W. Wee, "Chemical composition and antimicrobial activity of Cymbopogon nardus citronella essential oil against systemic bacteria of aquatic animals," Iran. J. Microbiol., vol. 5, no. 2, pp. 147-152, 2013.

[36] M. Ibadurrohman and P. P. Wulandari, "Synthesis of Methyl Ester Sulfonate Surfactant from Crude Palm Oil as an Active Substance of Laundry Liquid Detergent," in Proceedings of the 3rd International Symposium on Applied Chemistry 2017, 2017, vol. 1904, pp. 020058-1-020058-7.

[37] Y. F. Alli, L. Brioletty, H. Eni, and Y. Irawan, "Co-Surfactant Polyethylene Glycol Mono-Oleate In The Formulation Of Natural Based-Surfactant For Chemical EOR," Sci. Contrib. Oil Gas, vol. 40, no. 1, pp. 1-8, 2017.

[38] Y. Sampora, A. L. Juwono, A. Haryono, and Y. Irawan, "Study of Synthesis Polyethylene glycol oleate Sulfonated as an Anionic Surfactant for Enhanced Oil Recovery (EOR) Study of Synthesis Polyethylene glycol oleate Sulfonated as an Anionic Surfactant for Enhanced Oil Recovery (EOR)," in IOP Conf. Series : Journal of Physics : Conf. Series 909, 2017, pp. 1-7.

[39] B. Gevao, K. T. Semple, and K. C. Jones, "Bound pesticide residues in soils : a review," Environ. Pollut., vol. 108, no. 1, pp. 3-14, 2000.

[40] Z. Vryzas, "Pesticide fate in soil-sediment-water environment in relation to contamination preventing actions," Curr. Opin. Environ. Sci. Heal., vol. 4, pp. 5-9, 2018. 